\title{
Trajectory and Strategy Writer Erisca Febriani in Popular Literature: From Wattpad to Printing Novel
}

\author{
Liana Shinta Dewi ${ }^{1}$, Winasti Rahma Diani ${ }^{2}$, Agnira Rekha ${ }^{3}$ \\ \{lianashinta@untidar.ac.id,winastirahma@untidar.ac.id,agnirarekha@untidar.ac.id\} \\ ${ }^{1,2,3}$ Universitas Tidar, Magelang, Indonesia
}

\begin{abstract}
This article focuses on Wattpad novel, a platform for sharing writings, including a novel. Erisca Febriani is one of the Wattpad writers whose novels have been published by a publisher. Both the online and print version gets a positive response from its readers. In a popular literature context, it could be seen from the number of online readers and total printing. To get a positive reaction from its readers, a writer needs to have trajectory and strategy that in popular literature is necessary to achieve capital gain. Meanwhile, in the literature arena generally, Erisca as a writer or her novels, fights to win the arena. In analyzing the trajectory and strategy and her position in the literature arena, this article will use the theory of the cultural production arena presented by Pierre Bourdieu.
\end{abstract}

Keywords: Bourdieu, Erisca Febriani, popular literature, strategy, trajectory, Wattpad.

\section{INTRODUCTION}

Industrial revolution 4.0 becomes a popular term nowadays. According to Indonesian Ministry of Industry, Airlangga Hartanto [1] stated that Industrial revolution 4.0 marks by increasing the connectivity speed, interaction, and the border between man, machine, and other resources, which is convergent through information and communication technology. Connectivity and speed are the keys to the latest industrial revolution. It brings enormous effects on some life aspects, especially literature. The existence of Wattpad appears as one of the influenced matters.

Wattpad is a free application which can be used to upload and read literature work, especially novel. It is explained in Wattpad content guideline: "At Wattpad, we set stories with the goal of creating a safe and comfortable space for everyone to discover and create." Moreover, Wattpad has the rule "Wattpad services are only for 13 years old or over" and it is only for mature rating story/ literature work - stories which have sex and violence explicitly, either violence towards yourself or others, verbal or nonverbal violence - it can be accessed by people who are in age 17 or above (http://policies.wattpad.com/content/). Thus, they can access all stories in Wattpad.

It is easy to access this application. "You can't browse very much on the Site or use the service without registering for an account. To get the most out of the Wattpad platform, you'll need to register, choose an account name, and set a password." Commonly, the users who want to read stories in Wattpad do not need to register. However, they can easily access 
Wattpad if they sign up for its application. In making the user account, the users can directly link to Facebook, Google, or Gmail. After having the account, the users can easily upload their literature works/stories, get the reader's response, and vice versa.

The Wattpad platform enables anyone to be a writer. At least, in uploading the literature works, the users can improve their ability and the chance to be a writer will be more open. It happens to one of the authors in Wattpad, Erisca Febriani (EF).

EF comes from Lampung and she starts to write when she was in $8^{\text {th }}$ grade of Junior High School. Her popularity comes when she began to write her first novel, Dear Nathan (DN) and uploaded in Wattpad. Dear Nathan got a positive response from the readers and it is indicated by the number of readings that reached 7.5 million times (online version). Moreover, the readers of DN reached 33 million times. The readers' respond toward EF novels boost her to publish them to be printed.

Kurniasari in Jawa Pos [2] urged that Erisca once tried to publish her novel through selfpublishing. However, she had experienced deception. After going through these obstacles, the DN novel was finally published in a printed novel for the first time in 2016 by Best Media. The reader's reaction to the printed version is also as positive as the Wattpad version. The novel was first published in print in March 2016. Then, until May 2016, the DN novel has entered its fifth print. Furthermore, DN's popularity does not stop there. In the following year, 2017, the novel was produced into a feature film by Rapi Films.

DN brought EF's popularity. After writing DN, he continued to actively write and produce subsequent works, namely Hello Salma (HS), Serendipity (S), and Story for Gery (KG). The readers also gave positive responses to these novels. The level of readability of these novels is at least 1 million times. Generally, these novels talked about teenage love. Just like Dear Nathan, the novels are published through Wattpad before being published as a printed version.

The interesting point about the readers of EF novels is that they keep reading the printed version, even though they have read the novel on Wattpad. This is indicated by the printed version of the ordering service for readers of EF novels, for instance, in DN novels. The Wattpad version and the printed version have the same story. Even if there are differences, there are only a few sections that are not significantly influencing the story.

If literature and the entire aspects are seen as an arena, a writer is fighting to win the arena in various ways and various resources. It happens to EF. Then the question was come up regarding the strategies used by EF in its efforts to win the literary arena. In addition, a writer also cannot stand alone and she needs to be legalized from many sides to determine her existence in the literary arena. Both of these can be seen using the perspective of the theory of cultural production by Pierre Bourdieu.

Bourdieu describes the literary arena as "a place for struggles where at stake is the power to impose or impose a dominant definition of the author" [3]. The arena can also be understood as "the struggle or competition for certain positions so that social structure is something dynamic in which a person will move from one position to another" [4]. So, the arena can be imagined as an "imaginary space" in which it becomes and there is a struggle to win the arena. Among these, arenas is the arena of literature.

As well as other arenas, in the literary arena, some agents carry agencies. Agents can be understood as doers, "individuals become social subjects"[4]. Meanwhile, what is meant by the agency is "the ability to understand and control each other's actions based on the conditions in which the individual lives." Agency refers to the ability of individuals related to their relationship with the structure [4]. " 
The agent and her agency will carry out a series of strategies so that they become dominant in the arena which will ultimately be able to change or perpetuate social structures. According to Bourdieu, the strategy is "the product of the practice sense as the feel of the game" [5]. It can be interpreted that the strategy is a kind of social practice undertaken by an agent to win the arena. There are two strategies presented by Bourdieu, namely capital conversion strategy and capital reproduction strategy. The capital conversion strategy refers to the agent's efforts to convert the capital into another form of capital. Meanwhile, the capital reproduction strategy is an agent's attempt to use its capital to gain the same capital [6]. Moreover, the capital consists of four types, namely economic capital, cultural capital, social capital, and symbolic capital.

The strategies carried out by these agents are related to the trajectory that will be formed by the agent. Trajectory can be interpreted as a path. [3] states that the trajectory is "... a series of successive movements of an agent in a structured space (hierarchical), that occur replacement and distortion, or more precisely, in the distribution structure, different types of capital that will be staked in the arena, economic capital and specific consecrations."

In general, it can be illustrated that an agent will make movements in the literary arena and create certain trajectories. To create these trajectories, agents with the agency will use certain strategies that are supported by their assets.

\section{METHOD}

This study used qualitative research methods. Erisca Febriani's statements and statements relating to Erisca Febriani's works are the data that will be analyzed. The data is obtained through library studies that are more accessible through EF's social media, readers' comments and Erisca Febriani's posts, news articles that contain interviews with Erisca Febriani, and news articles that discuss EF's works.

In this study, the researchers looked at social practices carried out by Erisca Febriani concerning the novels she wrote, namely Dear Nathan, Serendipity, Hello Salma, and Story for Geri. Then, the researchers try to identify practices that fall into the category of strategies and trajectories classified by Bourdieu. After identifying these practices, the researchers interpret the results of the analysis to be conveyed to the readers.

\section{RESULT AND DISCUSSION}

\subsection{Erisca Febriani's Strategy}

There are two types of Bourdieu's strategies, namely the capital conversion strategy and the capital reproduction strategy. In addition, there are four types of capital, namely economic capital, cultural capital, social capital, and symbolic capital. Even though in gaining and using these capitals through some phases, she finally owns all four of the capitals. Thus, she does not obtain and use the four capitals at the same time.

Table 1. Erisca Febriani’s Publication List

\begin{tabular}{cccc}
\hline Novel & Wattpad & Printing Novel & Film \\
\hline
\end{tabular}




\begin{tabular}{lccc} 
Dear Nathan & 2016 & March 2016 & 23 March 2017 \\
Serendipity & 2016 & November 2016 & 9 August 2018 \\
Hello Salma & 2017 & March 2018 & 25 October 2019 \\
Kisah untuk Geri & 2019 & March 2019 & - \\
\hline
\end{tabular}

Table 1 shows a list of publications by Erisca Febriani. In the DN novel, EF uses economic and cultural capital. By using economic capital, the author has the capital (cost) to access the internet. The Internet makes EF's work exist in the Wattpad platform. In addition to economic capital, in DN, EF also uses cultural capital in the form of knowledge. She has the knowledge - which is not everyone knows - to access and then use Wattpad. By mobilizing these two capitals, EF produced DN's work.

In the $\mathrm{S}$ novel, EF uses economic, cultural and social capital. Similar to the DN novel, economic capital is related to EF's financial ability to be able to access the internet. EF also uses knowledge capital to access Wattpad and other social media, for example, Instagram, Facebook, Twitter and Ask.fm to promote S novels. In addition, she uses social capital in the form of a fan base that has formed after the DN novel gets a positive reception, even filmed. So, the popularity of DN novels and films gave the domino effect and became a social capital for EF in popularizing its next work, the $\mathrm{S}$ novel.

In the case of the HS and KuG novels, EF uses more capital. EF uses four capitals, namely economic, cultural, social and symbolic. The first capital, namely economic capital, was used by EF in connection with financial strength in accessing the internet to upload her writings. EF also has the financial power to provide services to pamper its fans. Second, cultural capital can be proven when EF uses capital in the form of knowledge to operate Wattpad and other social media.

Furthermore, in her success and popularity of films, EF uses a growing network of fans as its social capital to promote $\mathrm{HS}$ and KuG novels. Especially for HS novel which is a sequel to $\mathrm{DN}$, the network of fans is mainly obtained from fans of DN novels and films. In fact, in the newest novels, EF directly or indirectly uses symbolic capital as "the person who succeeded in creating a famous novel" as one of its capital. These capitals are then distributed into specific strategies. As it is explained by Bourdieu that there are two strategies, namely the capital conversion strategy and the capital reproduction strategy.

\subsection{Capital Reconversion Strategy}

The strategy of capital conversion or capital conversion mainly occurs from economic capital to social capital. This can be seen from EF's trajectories to access the internet. Accessing the internet is more paid than free. That is, EF has economic capital. This economic capital is combined with a cultural capital in the form of knowledge to access Wattpad. EF "Has been incorporated since September 2012". EF's strategy concerning economic and cultural capital can also be seen from creating accounts other than Wattpad, for example, 
Instagram, Facebook, Twitter and Ask.fm. By using this two capital, EF can surf in cyberspace, produce works, and get a fan base or social capital.

In addition to economic capital, the conversion strategy also occurs in social capital. EF converts social capital into economic capital. This can be seen from the voting conducted by EF. For instance, EF held a vote on the Instragam @ novelhellosalma account, before HS's novel was published in print, - the username of this account depends on the EF's novel. The first time, this account was called @ dearnathan.

"Jadiiiii, setelah dilakukan voting instagram @novelhellosalma minggu lalu. Ternyata banyak yang minta supaya di-update dulu di Wattpad terus baru diterbitin. Oke deh berhubung gue baik, nanti bakal gue posting lagi chapter 1 sampai chater 5 setelah gue selesai nulisnya [....]" (Febriani, Desember 2017).

"Sooooo, after the Instagram voting @ novelhellosalma was done last week, it turns out that many people are asking to be updated first on Wattpad and then published later. Ok, since I'm good, I'll repost chapter 1 to chapter 5 after I finish writing it [...] "(Febriani, December 2017).

Through voting, the readers feel happy because their opinions are responded.

"Oh, My...Good luck, Kak Eris, makasih banyak bersedia upload cerita ini di Wattpad. Sekali lagi makasih" (Dueg212, 2017).

"Oh, My ... Good luck, Eris, thank you very much for uploading this story on Wattpad. Thank you so much "(Dueg212, 2017).

These citations show that EF interacts with her fans regarding issues of the novel publication. It means that EF uses its social capital in the form of a DN novel fan base. Based on this interaction, EF can see the market share for its novels, which will eventually lead to financial gain. In fact, the voting conducted by EF can also be a HS novel teaser, which means the market will be increasingly formed. It shows that EF is converting social capital into economic capital.

In addition, the conversion of social capital into economic capital was also seen in the utilization of the popularity of the Dear Nathan film. This can be seen from the usage of DN film actors on its novel cover after the film was screened at the cinema. Dear Nathan's film was released in 2017 and watched by more than 750,000 viewers. In addition, not only the film's casts but Erisca Febriani also become more popular and known by many people. Then, viewers who have not read the novel are interested in buying a printed novel because in Wattpad the full version is no longer available.

Capital conversion also occurs from symbolic capital to economic capital. It proves from giving the EF's signature into the novel as a bonus. It is a usual matter in the pre-order session. For EF fans, everything related to EF is essential, including the signature. So, EF utilizes her popularity capital, symbolic capital as a writer to open markets or economic profits.

“.... Harga tetep 99.000 tapi belum termasuk ongkir. Dan ini dibatesin Cuma 500! Kalian juga bakal dapet TTD dalam bentuk kartu ucapan, jadi semua pemesanan PO bakal dapet kartu ucapan terima kasih yang di-TTD sama saya :p wkwk." 
"... The price is still 99,000, but it does not include the shipping. It is only 500! You will also get my signature in the form of a greeting card, so all PO orders will get a thanking card that is signed with my signature (wkwk)"

This quotation shows the close relationship between symbolic capital in the form of EF's popularity as a DN writer who is currently popular in Wattpad and the economic capital that EF wants to achieve through the publishing of printed novels. It is then strengthened by the number of people who make the PO actually reaching quota limits. The number of customers reached 1276 people.

\subsection{Capital Reproduction Strategy}

The strategy which is used by EF is not merely capital reconversion strategy but also capital reproduction strategy. It primary happens to economic capital. EF uses her finance to get financial advantages. It is showed from bonus giving and review competition.

EF gives the bonus to people who buy her novels, giveaway to her followers in social media, and special promo. For example, it is written by @erisca_febriani on her Twitter account:

"Nanya dong, kalau PO Thank You Salma enaknya bonusnya apa? Jawabnya pakai hashtag \#ThankYouSalma yak!”

"What kind of bonus if you want to order Thank You Salma? Answer it by mentioning \#ThankYouSalma!"

"Giveaway \#nungguinThankyouSalma

Tata cara:

1. FollowInstagram @thankyousalma

2. Like semua postingannya

3. Share poster ini di instagram dengan captiion menjawab pertanyaan: kenapa kamu nungguin cerita Thank you Salma?

4. Tag lima teman kamu untuk ikutan giveawaynya dan pakai hashtag \#Thankyousalma dan \#Nungguinthankyousalma"

5. Akan ada 2 totebag untuk dua pemenang yang akan diumumkan pada 1 Juli 2019. Good luck!!!!”

"Giveaway \#nungguinThankyouSalma

Steps:

1. Follow @ thankyousalma on Instagram

2. Like all posts

3. Share this poster on Instagram with the caption answering the question: why are you waiting for the Thank You Salma story?

4. Tag your five friends to join the giveaway and use the hashtag \#Thankyousalma and \#Nungguinthankyousalma " 
5. There will be two bags for the two winners which will be announced on July 1, 2019. Good luck !!!! "

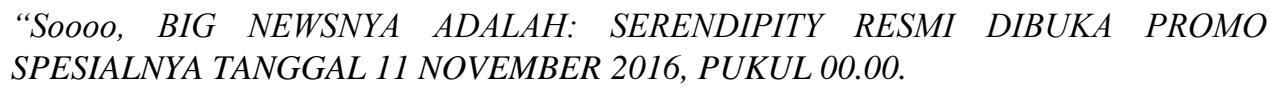

Harga Rp.89.000 (bekum termasuk diskon 20\% dan dapat bonus TTD + Phonestrap) setelah kalian baca novelnya, nanti kalian bakal tahu kalau phonestrap ini bener-bener berpengaruh dalam ceritanya. Jadi, buruan ikutan spesial promo sebelum menyesal di belakangan (lebay) haha karena phonestrap ini tidak dijual alias bonus khusus untuk spesial promo aja. Kebetulan ada 1000 kuota yang tersebar di 29 toko buku online...."

\begin{abstract}
"Soooo, THE BIG NEWS IS: SERENDIPITY OPEN SPECIAL PROMO OFFICIALLY ON 11 NOVEMBER 2016, 00.00 AM.

The price of Rp.89,000 (not including a 20\% discount and get a signature + Phone strap bonus) after you read the novel, you will know later that this phone strap is really influential in the story. So, join the special promo before you are regret haha. Because of this phone strap is not for sale or special bonuses for special promotions. Incidentally, there are 1000 items spread across 29 online book stores ..."
\end{abstract}

From these examples, EF spent economic capital on giving prizes to several readers. From the capital issue, EF can achieve even greater economic capital because of these methods. EF can promote his work, not only to his fans but also to those around him. That is, EF expands its market network. In addition, in these ways, EF can also guide fans to make pre-orders.In addition, in the strategy of reproducing economic capital, EF also holds a review competition. This is seen in the $\mathrm{KuG}$ novel.

\title{
"Halo Gengs,
}

Sudah punya buku manis yang satu ini?Atau belum punya? Cuss beli di toko buku dan toko online atau DM katadepan buat infopembelian.

Lalu, ikuti lomba reviewnya.

Aturannya sebagai berikut:

- followakun @ penerbitkatadepandan @eriscafebriani

- unggah (pusting) foto buku Kisah untuk Geri milikmu. Foto yang bagus dan instagramable tent jadi nilai lebih.

- Lengkapi dengan caption tentang kesanmu setelah membaca \#kisahuntukgeri bab mana yang paling menohok, dan baperable menurutmu, atau kesan yang lain.

DILARANG SPOILER YAAA!

- Tag 5 temanmu dan ajak mereka untuk beli, baca, dan ikut lomba review. 
3 orang pemenang akan mendapatkan uang tunai sebagai berikut.

Pemenang 1: $500 \mathrm{k}$

Pemenang 2: $300 k$

Pemenang 3: $200 k$

Dua pemenang lain: masing-masing paket buku senilai@200k”

"Hello Guys,

Have you grabbed this book? Please buy in book stores and online stores or DM katadepan for information on purchases.

Then, follow the review competition.

The rules are as follows:

-follow the @ penerbitkatadepan and @eriscafebriani accounts

Upload your photo of the Kisah untuk Geri. A good and instagramable photo has a big chance to win.

- Complete with a caption about your impressions after reading \#kisahuntukgeri, which chapters are most striking, and touchable in your opinion, or other impressions.

DO NOT SPOILER!

-Tag 5 of your friends and invite them to buy, read, and take part in the review competition.

3 winners will get cash as follows.

First Winner : $500 \mathrm{k}$

Second Winner : $300 \mathrm{k}$

Third Winner : 200k

Two other winners will get book package worth@ 200k each "

\subsection{Trajectory and Erisca Febriani's Existence in Literary Arena}

Before becoming a writer at Wattpad until finally becoming a writer in a printed novel, EF was a fanfiction writer. The term fan fiction refers to stories produced by fans based on plot lines and characters from either the single course text or else a "canon" of works; these fans created narratives often take the pre-existing story world in a new, sometimes bizzare, direction [7]. This style is quite popular among fans, especially fans of artists. This is illustrated in the following quote

“... Saya pernah gabung di Estikinatic, pernah menulis fanfiction tentang Ari karena terlalu lama nunggu kelanjutan kisahnya (di mana fanfiction itu terinspirasi dari seseorang di kisah nyata). Hal itu yang akhirnya buat saya mikir "kenapa gue justru nulis ff? kenapa saya nggak berusahanulis cerita baru? Tada, maka saya putuskan untuk menulis Dear Nathan. ...."

"... I once joined Estikinatic, once I wrote a fan-fiction about Ari because I waited too long for the continuation of the story (where the fan-fiction was inspired by someone in a 
true story). Finally, I thought, "why did I write ff instead? Why don't I try to write a new story? Here I am. I decided to write Dear Nathan. .... "

If this phase is included in EF's writing career, EF's trajectory as a writer is a fan-fiction writer. She wrote more of this style on the Facebook platform. Basically, even in this platform, she has started writing DN novels. However, she focused more on DN in the Wattpad platform.

Through this Wattpad platform, EF is gaining popularity. She is more focused on writing teen-lit than writing fan-fiction on this platform. This can be considered the second phase of her writing career. The trajectory occupied by EF is a teenage writer on the Wattpad platform. This then changes again as EF novels become more popular. The EF trajectory then turned into a teen-lit writer in print.

In Wattpad, EF's writing, as discussed in the background section, has many readers. The following is a list of EF achievements from the number of readers.

Table 2. Erisca Febriani Achievements

\begin{tabular}{|c|c|}
\hline Title & Achievements \\
\hline Dear Nathan & $\begin{array}{l}\text { It has been read } 32 \text { million times on Wattpad. } \\
\text { Gain } 54,000 \text { votes from Wattpad readers. } \\
\text { It is first published in } 2016 \text {. Currently, it has reached its } \\
\text { seventh printing. } \\
\text { In } 2017 \text {, Dear Nathan's novel was made into a film and } \\
\text { watched by more than } 700,000 \text { viewers. }\end{array}$ \\
\hline Serendipity & $\begin{array}{ll} & \text { It has been read } 3 \text { million times on Wattpad. } \\
\text { - } & \text { Gain174.000 voting from Wattpad readers. } \\
\text { - } & \text { It is filmed in } 2018 .\end{array}$ \\
\hline Hello Salma & $\begin{array}{l}\text { - } \quad \text { It has been read } 2 \text { million times on Wattpad. } \\
\text { - } \quad \text { Gain217.000 voting from Wattpad readers. }\end{array}$ \\
\hline Kisah untuk Geri & $\begin{array}{l}\text { - } \text { It has been read } 1 \text { million times on Wattpad. } \\
\text { - } \quad \text { Gain124.000 voting from Wattpad readers. } \\
\text { - } \quad \text { It is performed as \#2 best seller in Gramedia book store } \\
\text { - } \quad \text { It has performed as \#3 'most wanted book' in Gramedia book } \\
\text { stores. }\end{array}$ \\
\hline
\end{tabular}

In general, the measurement of Ef's and EF's novels success is measured by the number of readers and the number of reprints. This means EF novels can be categorized in popular literature. It is consistent with one of the definitions expressed by Raymond William regarding 
popular literature. One of the popular literary definitions, according to him, is "the kind of work that many people like" [8]. This appears in EF's series of works and authorship.

EF's position in the literary arena is more determined by the reading community, especially among adolescents. The literary arena and its positions, according to Bourdieu, are largely determined by the legitimacy of the people outside. This legitimacy makes a writer and his work legitimate or not in the literary arena. This is also what ultimately makes the writer can be recognized as a writer and his work as literature or not.

In EF's case, the work that she wrote was more legitimized by readers who were mostly teenagers. This shows that the legitimacy obtained by EF is mostly in the form of popular legitimacy. According to Bourdieu, legitimacy is the legitimacy that obtained from a mass audience. Furthermore, Bourdieu likens that literature is actually in a double hierarchy position. On the one hand, literature refers to a degree of aesthetic success that is usually in the form of recognition from writers who also have legitimacy and on the other hand, literature is bound to sales figures in the market [9]. In the case of EF, legitimacy is coming from the market, while aesthetic legitimacy, the recognition of fellow writers who have legitimacy, has not been seen.

\section{CONCLUSION}

EF's authorship journey shows that the literary arena, at present, is experiencing an expansion of the realm. In the industrial era 4.0, the literary arena must also consider online media. This has actually begun to be done by some publishers, although it is still limited to stories that are popular. Ultimately, this will also have an impact on the legitimacy that obtained by literary writers in online media. EF tends to have popular legitimacy. However, in industry 4.0, new possibilities are always open in the realm of the literary arena so that this kind of pattern is also possible to change.

\section{References}

[1] J. Darmawan, "Menjadi Guru Era Pendidikan 4.0 - Serambi Indonesia." [Online]. Available: https://aceh.tribunnews.com/2018/11/27/menjadi-guru-era-pendidikan-40. [Accessed: 03-Jan-2020].

[2] F. Kurniasari, "Erisca Febriani, Penulis Novel Dear Nathan: Menulis Itu Hak Siapa Saja."

[3] P. Bourdieu, Arena Produksi Kultural: Sebuah Kajian Sosiologi Budaya (Penerjemah Yudi Santosa). Yogyakarta: Kreasi Wacana, 2015.

[4] K. Y. Karnanta, "Paradigma Teori Arena Produksi Kultural Sastra: Kajian Terhadap Pemikiran Pierre Bourdie,” J. Poet., vol. 1, no. 1, pp. 3-15, 2013.

[5] S. Anwar, Persada Studi Klub dalam arena sastra Indonesia. Yogyakarta: Gadjah Mada University Press, 2015.

[6] P. Bourdieu, Distinction : a social critique of the judgement of taste. Harvard University Press, 1984.

[7] Bronwen Thomas, "What Is Fanfiction and Why Are People Saying Such Nice Things about It??," Storyworlds A J. Narrat. Stud., vol. 3, no. 2011, p. 1, 2011, doi: 10.5250/storyworlds.3.2011.0001.

[8] J. Storey, Cultural Theory and Popular Culture. England: Pearson Education, 2019.

[9] P. Bourdieu, Sociological Perspectives on Sport: The Games Outside the Games, 2nd edition. Taylor and Francis Inc., 2015. 
